\title{
Assessing the extent and use of risk analysis methodologies in Africa, using data derived from the Performance of Veterinary Services (PVS)
} Pathway

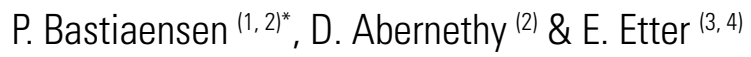 \\ (1) World Organisation for Animal Health (OIE), Regional Representation for Eastern Africa, \\ P.O. Box 19687, 00202 Nairobi, Kenya \\ (2) Department of Veterinary Tropical Diseases, Faculty of Veterinary Science, University of Pretoria, \\ P/Bag X04, Onderstepoort 0110, Pretoria, South Africa \\ (3) UMR 117 ASTRE, Department BIOS - Centre de coopération internationale en recherche agronomique \\ pour le développement (CIRAD), Montpellier, France \\ (4) Epidemiology Section, Department of Production Animal Studies, Faculty of Veterinary Sciences, \\ University of Pretoria, P/Bag X04, Onderstepoort 0110, Pretoria, South Africa \\ *Corresponding author: p.bastiaensen@oie.int; office@bastiaensen.co.za
}

\begin{abstract}
Summary
African countries that wish to export are increasingly faced with import risk assessments from importing countries concerned about the sources of their imported goods. Other risk analysis methodologies and approaches are also employed, which focus on animal and human health within countries and communities.

Based on an analysis of evaluations conducted by the World Organisation for Animal Health (OIE), using the Performance of Veterinary Services Tool, the authors attempt to define current practice in Africa and degrees of compliance with the World Trade Organization Agreement on the Application of Sanitary and Phytosanitary Measures ('SPS Agreement') and OIE standards. To assist in this task, the authors also make use of a review of selected risk assessment reports.

Results point to a lack of technical capacity and capability to conduct risk assessments in compliance with OIE standards (except in the case of three countries), ranging from an outright absence of any form of (documented) risk assessment and consecutive risk management decisions (level of advancement 1 ) to shortcomings in one or several aspects of the risk assessment process. This is confirmed by a number of case studies, half of which have been produced by international consultants.

The major recommendations of this paper are i) to strengthen the human resources pool for conducting risk assessments and ii) to establish dedicated risk assessment units, with clear terms of reference, job descriptions and policies, procedures and protocols.
\end{abstract}

\section{Keywords}

Africa - Agreement on the Application of Sanitary and Phytosanitary Measures - Animal Animal product - Import - OIE - Performance of Veterinary Services evaluation - Risk analysis - Risk assessment - Trade - World Organisation for Animal Health - World Trade Organization.

\section{Introduction}

Many countries in Africa are working on delivery and inspection systems that would eventually allow them to certify animals and animal products for export onto world markets, primarily those that pay high premiums for such commodities. Prospective exporters are, however, increasingly being faced with risk assessment reports from importing countries which recommend against importing their goods.

The principle of such (import) risk analysis, depending on the legal framework, was established by the adoption of the 
Agreement on the Application of Sanitary and Phytosanitary Measures (the 'SPS Agreement'), which entered into force with the establishment of the World Trade Organization (WTO) on 1 January 1995. It stipulates, under Article 5, that: '... Members shall ensure that their sanitary or phytosanitary measures are based on an assessment, as appropriate to the circumstances, of the risks to human, animal or plant life or health, taking into account risk assessment techniques developed by the relevant international organizations' (1). The organisations referred to are the World Organisation for Animal Health or OIE (for animal health), the Codex Alimentarius Commission (for food safety) and the International Plant Protection Convention or IPPC (for plant health).

Over and above trade-related import risk analyses, there are other risk analysis methodologies and approaches geared towards clarifying the consequences of an existing or emerging hazard to animal health, food safety, human health and even to the environment and biodiversity. Risk analyses are also used to highlight biological threats or micro-biological genetic threats, such as the emergence of antimicrobial resistance.

Whether they are employed to assess cross-border trade risks or internal risks, risk assessments and the broader concept of risk analysis have become central to a number of decision-making processes in many developed countries. In developing countries, however, there is a general belief that such analyses are extremely rare, mainly because the volumes of traded goods (in the case of imports) do not justify engaging in this process, or because government decision-makers are unfamiliar with the concept as a way of quantifiably measuring the potential consequences, for a variety of stakeholders, of an emerging hazard within their country.

The many OIE Performance of Veterinary Services (PVS) evaluation missions conducted in developing and intransition countries seem to indicate that there is a lack of capacity to conduct risk analyses, either for the purpose of managing import risks, or to refute reports from trading partners. This weakness is detrimental to a country's ability to avoid the introduction of exotic animal pathogens or the spread of animal pathogens to trading partners, to its ability to access lucrative foreign markets and to its capacity to manage domestic emerging hazards.

In this paper, the authors present some aspects of risk analysis and, in particular, risk assessment, as conducted in Africa today, based primarily on an analysis of the relevant critical competencies in PVS reports of evaluations undertaken in Africa.

\section{Risk analysis and risk assessment}

Central to risk analysis is the concept of hazard. Once a hazard has been identified, this will guide further processes within the risk analysis framework. Risk assessment estimates the likelihood that a particular hazard will occur and, if it does occur, what the consequences may be. Other steps include preventing any occurrence of the hazard; the proposed management of risk, should the hazard occur; and aspects of risk communication. Risk analysis is applied to a wide range of industries, e.g. the aeronautics and space industry, the nuclear power industry, the banking and insurance sectors, and the health sector. In international trade, it is related to the sanitary and phytosanitary (SPS) aspects of plant and animal production and their products, whether intended for human consumption or not.

In the livestock sector, the application of risk analysis and risk assessment by government departments and agencies, depending on the legal framework of the country concerned, is based on the WTO SPS Agreement, which stipulates that: "...Members shall base their sanitary or phytosanitary measures on international standards, guidelines or recommendations, where they exist...' (1). The international (binding) standards for conducting risk analyses for terrestrial animals and (primary) animal products, such as fresh meat, milk, eggs and honey, are laid down in Chapter 2.1 of the Terrestrial Animal Health Code (Terrestrial Code) on import risk analysis (2) with two accompanying (non-binding) handbooks on the subject, one providing guidelines on qualitative risk assessment (3) and the other on quantitative risk assessment (4). These international OIE standards and guidelines do not, as yet, cover all other types of risk assessment. In the specific case of risk assessments involving wildlife, the International Union for the Conservation of Nature (IUCN) and the OIE have issued guidelines, with an accompanying manual, the Manual of Procedures for Wildlife Disease Risk Analysis (5). Since January 2016, aspects of antibiotic resistance have been covered by a new OIE international standard on risk analysis for antimicrobial resistance, arising from the use of antimicrobial agents in animals, as included in the new Chapter 6.10 of the Terrestrial Code (2). For products of animal origin which have undergone further processing down the value chain, the standards of the Codex Alimentarius Commission apply; principally, the Working Principles for Risk Analysis for Food Safety for Application by Governments (CAC/GL 62-2007) (6).

In a number of cases, national governments and private entities have developed their own risk assessment handbooks and guidelines, based, to a varying degree, on the overarching OIE standards. 


\section{OIE standards on the quality of Veterinary Services and the PVS Pathway}

Since 2006, the OIE has implemented the PVS Pathway, a global programme for the sustainable improvement of a country's compliance with OIE standards on the quality of Veterinary Services (7). The programme is directly based on two chapters of Section 3 of the OIE Terrestrial Code (2), dealing with the quality of Veterinary Services (Chapters 3.1 and 3.2). Using a standardised and objectively measurable approach, a tool has been developed and published as the 'OIE Tool for the Evaluation of the Performance of Veterinary Services' (or the OIE PVS Tool) (8). It is the OIE's main operational tool to encourage government Veterinary Services (Veterinary Authorities) to improve animal and public health and enhance compliance with SPS standards, whether at the national level or, in terms of transparency and trade, at the regional and international level (7). More than 128 countries worldwide have undergone - at their own request - such initial, independent external PVS evaluations, carried out by OIE-certified PVS experts, whilst numerous countries have also benefited from PVS evaluation follow-up missions, intended to update the information collected. Most countries participating in this programme are developing or in-transition economies, with a few recent exceptions, such as Australia, Iceland and Japan (9).

The PVS evaluation reports (whether initial or follow-up) provide detailed insight into a country's compliance with international standards, based on 47 Critical Competencies (CCs), grouped under four Fundamental Components (8). Each CC is clearly defined and referenced to the corresponding international standard, and allows for one of five levels of advancement to be selected by the PVS evaluation experts conducting the mission, supported by a narrative, and documented evidence. One of these 47 CCs, under the Fundamental Component, 'Technical authority and capability', is CC.II.3., 'Risk analysis'. It is linked to Chapter 2.1, 'Import risk analysis', of the Terrestrial Code, defined as: 'The authority and capability of the Veterinary Services (VS) to base its risk management measures on risk assessment'. Five levels of advancement are suggested, from Level 1 (little or no compliance) to 5 (full compliance with the international standard or standards) (Table I).

Once finalised and approved by the beneficiary country, the PVS evaluation report can, at the request of the country:

- be released into the public domain, in which case it is available on the OIE websites for download
- be shared with a selected group of regional and technical agencies and bilateral and multilateral donor agencies and governments, or

- remain the property of the beneficiary government, not intended for further dissemination.

\section{Approach to analysing PVS reports and estimating the scope of risk assessments}

This paper presents selected parts of a wider investigation conducted in 2015 and 2016 as part of an academic assignment by the first author:

- a continent-wide survey conducted amongst Directors of Veterinary Services in Africa

- an analysis of the outcomes of PVS evaluation and evaluation follow-up reports, with respect to CC II.3., 'Risk analysis', and

- a review of a selection of submitted risk assessment reports (case studies).

For the current paper, the authors focus mostly on aspects pertaining to PVS evaluations. Of the 54 countries on the African continent, 51 have benefited from at least one PVS evaluation mission. Out of these 51 reports, seven reports have not been released for further dissemination by their governments, leaving 44 reports available for scrutiny and analysis. In these cases, only the most recent report (the follow-up report, if not, the initial evaluation report) was used in the analysis.

The reports were retrieved from the OIE online database, where all publicly accessible and partially restricted reports are available for download to OIE staff and authorised staff of regional and technical agencies, as well as bilateral and multilateral donor agencies and governments. Most data presented in this part of the paper are anonymous, as most PVS reports have not been cleared for the public domain.

The collection of data focused on CC II.3., 'Risk analysis'. The authors retrieved the levels of advancement awarded to various countries, and studied the document explaining the reasons for the scoring and possible remedial measures or recommendations to improve the level of advancement in the future.

Based on these compiled data, countries were then asked to submit risk assessment reports for further scrutiny, to assess their compliance with the OIE guidelines on (import) risk 
assessment. Four countries submitted reports and these were analysed using the template for the structure of a (qualitative) import risk analysis on page 60 of Volume I of the OIE Handbook on Import Risk Analysis for Animals and Animal Products (3). The purpose was to identify (as a binary input: yes/no) whether or not the various criteria of an import risk analysis had been properly addressed and described in the report, but not to analyse the report's contents from a technical perspective. In addition to the criteria listed in the template, some of the other criteria discussed in the Handbook were added to the list.

\section{Results of the analysis of PVS reports}

The vast majority of countries in Africa (93\%) are situated at Levels 1 or 2 of advancement (Table I), meaning that risk management measures, such as the decision to allow or refuse applications for import, are not usually based on (a documented) risk assessment (Level 1), or that there is some

\section{Table I}

Levels of advancement ( 1 being the lowest and 5 the highest) which African countries have achieved and the number of countries which have achieved it

\begin{tabular}{|c|c|c|}
\hline $\begin{array}{l}\text { Level of } \\
\text { advancement }\end{array}$ & $\begin{array}{c}\text { No. of } \\
\text { countries }\end{array}$ & Definition of the level of advancement \\
\hline 1 & 19 & $\begin{array}{l}\text { Risk management measures are not usually } \\
\text { supported by risk assessment }\end{array}$ \\
\hline 2 & 22 & $\begin{array}{l}\text { Veterinary Services compile and maintain data } \\
\text { but do not have the capability to carry out risk } \\
\text { analysis. Some risk management measures } \\
\text { are based on risk assessment }\end{array}$ \\
\hline 3 & 3 & $\begin{array}{l}\text { Veterinary Services compile and maintain } \\
\text { data and have the capability to carry out risk } \\
\text { analysis. The majority of risk management } \\
\text { measures are based on risk assessment }\end{array}$ \\
\hline 4 & 0 & $\begin{array}{l}\text { Veterinary Services conduct risk analysis in } \\
\text { compliance with the relevant OIE standards, } \\
\text { and base their risk management measures on } \\
\text { the outcomes of risk assessment }\end{array}$ \\
\hline 5 & 0 & $\begin{array}{l}\text { Veterinary Services are consistent in basing } \\
\text { sanitary measures on risk assessment, and } \\
\text { in communicating their procedures and } \\
\text { outcomes internationally, meeting all their OIE } \\
\text { obligations (including WTO SPS Agreement } \\
\text { obligations, where applicable) }\end{array}$ \\
\hline Total & 44 & \\
\hline
\end{tabular}

OIE: World Organisation for Animal Health SPS Agreement: Sanitary and Phytosanitary Agreement WTO: World Trade Organization form of data collection by the Veterinary Services but they lack the capability to carry out risk analysis, although some risk management measures are based on risk assessment (Level 2).

The pooling of results by region (central, eastern, northern, southern and western Africa) gives a broad (and anonymous) indication of where capacities for risk analysis are available and where they are absent (as a percentage of the countries of that region) (Fig. 1).

Of the three countries at Level 3 of advancement, two have agreed to full disclosure of their PVS report(s): the Republic of South Africa and the Kingdom of Swaziland. The three countries, through their Veterinary Services, have the capacity to: 'compile and maintain data and have the capability to carry out risk analysis. The majority of risk management measures are based on risk assessment'.

In the case of South Africa, specific reference is made in the narrative (supporting the choice of its level of advancement) to risk assessments completed for the importation of pork from countries where porcine reproductive and respiratory syndrome is present, and the importation of sable antelope (Hippotragus niger) from Zambia. The appendices also make reference to risk analysis of the importation of sheep and goats and genetic material from scrapie-positive countries, the risk associated with the importation of Ethiopian butter into South Africa, and the risk associated with importing pet rabbits into South Africa (no dates given for any of these). The point is also made that a risk analysis of avian influenza management (in the ostrich industry) was carried out by an independent foreign consultancy, at the request of the South African Ostrich Business Chamber, which - at the time - decided that the national Veterinary Authority was not able to provide such independent risk analysis (10). The

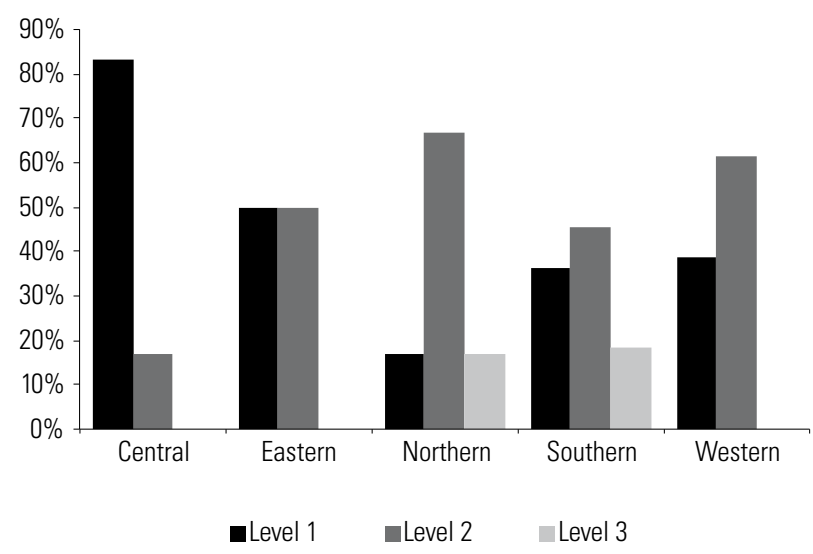

Fig.1

Levels of advancement (1 to 3 ) of countries in Africa

Countries are pooled per geographical region, as a percentage of the total number of countries per pool: central Africa (7 countries), eastern Africa (8), northern Africa (6), southern Africa (11) and western Africa (13) 
PVS report also points to the lack of risk analysis for most animal health programmes, leading to the continuation of unrealistic targets and strategies which are then not achieved (e.g. bovine tuberculosis, brucellosis, anthrax).

In the case of Swaziland, it was stated that: 'several formal risk assessments have been performed either by the Veterinary Epidemiology Unit alone or in collaboration with external experts. Risk assessment was used to develop the 2007 National Avian Influenza Preparedness Plan. In 2010 a qualitative risk assessment on the movement of wild game from the Republic of South Africa into the Big 6 Game Reserve in Swaziland was done in collaboration with external expertise.' However, the point is also made that there was: '. . . little documentation available regarding the use of risk assessment as an integral part of decision making and policy development'.

In the third country (undisclosed), it was stated that risk assessments are conducted almost systematically to define import conditions, resulting in mostly consistent import procedures. However, some imports are systematically refused, based on outdated regulations, for which risk assessment could demonstrate the (likely) absence of risk. As for Swaziland, the point is made that there is a need to systematically document, archive and formalise risk analysis.

In the remaining countries, most levels of advancement were justified by the outright absence of any form of (documented) risk assessment and consecutive risk management decisions (Level 1), or shortcomings in one or several aspects of the practice of risk assessment (Level 2), as summarised in Tables II and III, based on an analysis of the narrative findings and recommendations.

Recommendations aimed at improving Veterinary Services at Level 1 usually point to the need to establish a risk analysis (or disease intelligence) unit, with dedicated staff and appropriate databases. Furthermore, the Veterinary Services concerned should analyse data from various domestic and foreign/external sources, provide relevant training to staff, and better document those risk assessments that have been conducted, as well as the risk management decisions taken as a result. In a limited number of cases (three), the recommendation is that very advanced skills development is not needed, since the straightforward use of publicly available information and of international standards, such as the OIE and Codex Alimentarius standards, is sufficient to mitigate risks, given the geographical, trade and animal health context of the country.

One statement may at once allow a country to exceed Level 1 but prevent it from attaining Level 3. For example: 'Only import risk analysis is conducted, there is no focus on risks arising at the domestic level'. This indicates that there is the capacity to conduct risk analysis, but that the scope is partial (for imports only).

Recommendations regarding Level 2 are similar to, but more specific than, those made for countries at Level 1 and recommend, amongst other things:

- establishing a risk analysis unit (or similar), with dedicated staff and appropriate databases

- reorganising or redesigning data collection streams to improve the quality and quantity of data, whether domestic or foreign

- carrying out analysis of data from various domestic and foreign/external sources

- formalising policies, protocols and procedures, based on OIE guidelines

- providing relevant training to staff (even within the country)

- improving the documentation of risk assessments and subsequent risk management decisions.

\section{Table II}

Most common findings for African countries gaining Level 1 of advancement

Level 1: 'Risk management measures are not usually supported by risk assessment.'

\begin{tabular}{l}
\hline Findings (in decreasing order of frequency) \\
\hline No evidence of any form of documented risk assessment. Blanket import bans indicate lack of scientific justification for risk management \\
measures. No overall capacity available. No formal risk analysis unit \\
No staff available or available staff have not been trained in risk assessment or trained staff have been deployed elsewhere \\
Past experience in limited-scale risk assessment is still available (field-level surveillance), or risk assessments are conducted by external experts, \\
at the regional level, focusing on target diseases only (avian influenza, vector-borne diseases...) \\
Data are collected, mostly at field level, and transferred, but no (regular, dynamic) data processing is taking place \\
No formal policies, protocols or procedures exist to indicate when formal risk assessments should be conducted \\
Political interference hampers turning risk assessment outcomes into risk management measures
\end{tabular}




\section{Table III}

\section{Most common findings for African countries gaining Level 2 of advancement}

Level 2: 'Veterinary Services compile and maintain data but do not have the capability to carry out risk analysis. Some risk management measures are based on risk assessment.'

\begin{tabular}{|c|c|}
\hline Findings that allow a country to exceed Level 1 (in decreasing order of frequency) & Frequency \\
\hline Data are collected, mostly at field level, and transferred to the national level & 6 \\
\hline Staff have been trained in risk analysis, or are currently undergoing training & 6 \\
\hline Import risk analysis is conducted, even though there is no focus on risks arising at the domestic level & 4 \\
\hline Domestic risk analysis is conducted, though it is focused on foot and mouth disease only, from an export perspective (beef) & 4 \\
\hline There is general awareness, at the national level, of the need for scientifically founded risk management decisions and the value of risk assessments & 3 \\
\hline Legislation exists to support the practice of risk assessment and risk analysis in general & 3 \\
\hline Data are compiled into a database (sometimes networked, intra-net) & 2 \\
\hline Risk management decisions are based on international standards (OIE, Codex, SPS Agreement) & 2 \\
\hline $\begin{array}{l}\text { A dedicated risk analysis (or similar) unit exists (e.g. a disease intelligence unit, epidemiology unit, surveillance unit, central information management } \\
\text { unit, etc.) }\end{array}$ & 2 \\
\hline Qualitative risk assessment is conducted (though there may be no capacity to conduct quantitative risk assessment) & 1 \\
\hline Risk analysis is focused on highly pathogenic avian influenza only, from an import risk perspective (poultry) & 1 \\
\hline Findings that prevent a country from attaining Level 3 (in decreasing order of frequency) & Frequency \\
\hline No genuine risk assessments are conducted, or they are not documented. Hazard identification is conducted, at best & 8 \\
\hline There are no formal policies, protocols or procedures to guide staff on when formal risk assessments should be conducted & 7 \\
\hline There is a lack of trained or qualified staff & 6 \\
\hline There is no dedicated risk analysis unit & 5 \\
\hline Only import risk analysis is conducted, there is no focus on risks arising at the domestic level & 5 \\
\hline There is no database to integrate data collected from various sources & 4 \\
\hline Data are collected, mostly at the field level, but are not reliable or vary in quality & 3 \\
\hline Risk analysis is focused on foot and mouth disease only, from an export perspective (beef) & 3 \\
\hline Data collected are insufficient to support risk assessments, or remain under-used & 2 \\
\hline There are no staff appointments, clear positions and/or job descriptions & 2 \\
\hline There is no legislation to support the practice of risk assessment and risk analysis in general & 1 \\
\hline There is a lack of operational (financial, material) means to conduct risk assessment & 1 \\
\hline There is no capacity to conduct quantitative risk assessments (only qualitative risk assessments are conducted) & 1 \\
\hline
\end{tabular}

OIE: World Organisation for Animal Health

SPS Agreement: Agreement on the Application of Sanitary and Phytosanitary Measures

At times, there is also a recommendation to strengthen (secondary) legislation, improve working conditions (transport, Internet access...) and to implement regional risk assessment approaches (e.g. for avian influenza in West Africa).

\section{Estimating the scope of risk assessments}

The four risk assessments (Tables IV and V) submitted by participating countries were analysed according to the OIE Handbook on Import Risk Analysis for Animals and Animal Products (3). All these reports presented qualitative risk assessments, but only three represented genuine import risk assessments. Assessment D in Tables IV and V was a risk analysis of the type used to convince potential trading partners of the safety of the commodities proposed for export; in this case, fresh and heat-treated ostrich meat for the European Union. As a result, not all aspects of the methodology laid out in the Handbook (3) are applicable, e.g. entry assessment, and Assessment D focuses mainly on risk management measures that can be applied to ensure the safety of the commodity proposed for export. In addition, because of the fact that the targeted market is clearly determined, the report concentrates on the applicable European Commission (EC) directives (2007/777/EC and 2008/798/EC), rather than on the more general terms of the applicable chapters of the OIE Terrestrial Code. 
Table IV

Case studies of (import) risk assessment reports in African countries

\begin{tabular}{ll}
\hline Title of risk assessment report (reference) & Commissioned by \\
\hline $\begin{array}{l}\text { A. Risk assessment and proposed management of cattle to be imported from Eldoret, } \\
\text { Kenya, to Kagera, Tanzania (11) }\end{array}$ & Ministry of Livestock and Fisheries Development, Tanzania \\
$\begin{array}{l}\text { B. A qualitative assessment of the risk of introducing peste des petits ruminants into } \\
\text { northern Zambia from Tanzania (12) }\end{array}$ & Ministry of Agriculture and Livestock, Zambia \\
$\begin{array}{l}\text { C. Import risk analysis: sable antelope from Zambia into South Africa (13) } \\
\text { D. Managing and controlling the threats of avian influenza viruses (AIV) to the ostrich } \\
\text { industry of South Africa (10) }\end{array}$ & Department of Agriculture, Forestry and Fisheries, South Africa \\
\hline
\end{tabular}

\section{Table V}

Case studies of (import) risk assessment reports: description of features and items included, with reference to the OIE Handbook on Import Risk Analysis for Animals and Animal Products (3)

\begin{tabular}{|c|c|c|c|c|}
\hline OIE template for an import risk analysis report & Report A & Report B & Report C & Report D \\
\hline Date & $\bullet$ & $\bullet$ & $\bullet$ & $\bullet$ \\
\hline Title & $\bullet$ & $\bullet$ & $\bullet$ & - \\
\hline Context & • & - & • & • \\
\hline Purpose & $\bullet$ & $\bullet$ & $\bullet$ & • \\
\hline Quantitative risk analysis* & - & - & - & - \\
\hline Type of risk analysis* & Bilateral & Bilateral & Bilateral & Multilateral \\
\hline Risk communication strategy & $\bullet$ & $\bullet$ & • & - \\
\hline Executive summary & Abstract & - & - & • \\
\hline Hazard identification & $\bullet$ & $\bullet$ & $\bullet$ & $\bullet$ \\
\hline Risk scenario tree $(s)^{*}$ & - & - & - & - \\
\hline Animal health measures in the Code & - & - & • & $\bullet$ \\
\hline Risk assessment (scales) & 4 & 3 & 5 & - \\
\hline - Entry (release) assessment & $\bullet$ & - & $\bullet$ & - \\
\hline - Exposure assessment & $\bullet$ & - & $\bullet$ & - \\
\hline - Consequence assessment & $\bullet$ & - & $\bullet$ & - \\
\hline - Risk estimation & $\bullet$ & - & $\bullet$ & - \\
\hline - Risk management & - & $\bullet$ & $\bullet$ & • \\
\hline Conclusions and recommendations & $\bullet$ & $\bullet$ & - & $\bullet$ \\
\hline References & $\bullet$ & - & $\bullet$ & $\bullet$ \\
\hline Number of pages* & 10 & 10 & 77 & 42 \\
\hline
\end{tabular}

* Criteria not included in the OIE template but added for the purposes of this study

\section{Discussion}

The results presented in this paper, i.e. the outcomes of the PVS evaluations, point to a lack of technical capacity and capability to conduct risk assessments and, more broadly, risk analysis, in compliance with OIE standards (and guidelines, where import risk analysis is concerned). Whether this lack translates into major problems for international producers wanting to enter African markets or for African producers trying to access international markets is difficult to gauge, given the very small proportion, around one percent, that Africa's exports represent on international markets for products such as beef, pork and chicken (14). The SPS Information Management System (15) provides insight into the way in which African countries that are Members of the WTO interact with their trading partners. Out of 160 specific trade concerns brought to the attention of the SPS Committee since June 1995, concerning animal-related issues (excluding aquatic animals and their products), only five cases were brought against African countries: Egypt, Senegal and three cases against South 
Africa. None of the measures challenged in these cases was argued on the basis of (faulty) risk assessments carried out by the country imposing the measure. Nor were any related to risk assessments brought forward by the countries raising the concern in an attempt to invalidate the measure. These cases were principally argued on the international standards/harmonisation' provisions of the SPS Agreement. Worldwide, only $12 \%$ of cases (20 out of 160 ) included 'risk assessment' (among other items) as part of the challenge, either to challenge an initial risk assessment or suggest an alternative risk assessment to counter the measure.

The point needs to be made here that OIE standards and guidelines cover import risk analysis only, whereas the evaluation conducted as part of a PVS mission deals with risk analysis in the broader sense, including surveillance and monitoring of domestic risks threatening local consumers, the animal population or even biodiversity. In addition, and perhaps because of the above considerations, an analysis of PVS reports suggests that there is a wide range of interpretation of CCs on 'risk analysis' amongst OIE-trained and accredited PVS experts, with some experts looking at the capacity to conduct import risk analysis only, in line with the OIE standards in force, whilst others cover much more ground. The fact that provisional 'suggested' indicators, included in the PVS Tool up to edition five (16), were later abandoned (from the current edition six onwards) may account for some, but not all, of the discrepancies noted.

Keeping the above considerations in mind, 93\% of the countries whose PVS reports were analysed, i.e. 41 out of 44 countries, are regarded as having no or little capability to undertake risk assessments on which they can base their risk management measures (such as prohibiting the import of certain commodities). The three best-performing countries in Africa, situated in southern Africa (Swaziland and South Africa) and northern Africa (undisclosed), are granted Level 3 of advancement. This means that they do not comply with relevant OIE standards or base their risk management measures on the outcomes of risk assessment (the requirements for Level 4), and they fail to communicate their procedures internationally (Level 5).

In most cases where countries are granted only Level 1 , the main reasons are:

- the absence of any form of documented evidence of risk assessment, whether for import or otherwise

- lack of staff in general

- lack of staff trained in risk analysis

- evidence, sometimes, of rather irrational blanket bans on certain commodities, which are clearly not based on risk assessment and could be challenged by trading partners under the terms of the SPS Agreement.
In the slightly better scenario of Level 2, there is evidence that:

- staff have been trained

- data are being collected that may be of use in (future) risk assessments, and/or

- some risk assessments are being developed, though with a narrow scope, e.g. only on exports, or only on imports, or only on one particular disease.

In a number of cases, PVS experts make the point that there may not be a need to engage in very advanced skills development on risk analysis, arguing that straightforward use of publicly available information and the use of international standards, such as those of the OIE and Codex Alimentarius, are sufficient to mitigate risk.

Whilst this is certainly true for countries whose trade volumes do not justify the effort and cost of developing fully fledged risk assessment reports, the fact remains that an 'understanding' of general risk assessment (and management) principles is of paramount importance and requires appropriately qualified personnel, irrespective of which sources of information are being used and to what degree risk assessments are formal, qualitative, quantitative or merely partial (but always well documented).

Furthermore, the use or application of internationally agreed OIE standards, as listed in, for example, the Terrestrial Code, are not incompatible with conducting risk assessments. This is well illustrated by an import risk analysis for sable antelope from Zambia (13), which lists no fewer than 27 hazards (pathogenic agents), many of which are OIElisted diseases for which risk mitigation measures are available, widely agreed upon and applied.

On the other hand, whilst a risk assessment may have been conducted according to OIE methodology, reliance on OIE standards alone may not ensure access to target markets, especially when the appropriate level of protection (ALOP) put forward by certain countries or trading blocs is higher than that recommended by the OIE (or Codex Alimentarius). Hence, countries may want to align their scientific arguments to those of the target market(s), rather than to an international benchmark, as the risk analysis commissioned by the South African Ostrich Business Chamber (10) clearly demonstrates (by focusing on EC Directives, rather than the applicable OIE standards).

The major recommendations from the PVS experts and their reports are:

- to strengthen the human resources pool

- to consider establishing dedicated risk assessment units, with clear terms of reference, clear job descriptions for 
staff and clear policies, procedures or protocols to guide decisions on if, when and how risk assessments should be conducted and how they should be documented and archived.

Another important recommendation concerns the need to document the outcomes of risk management decisions, as a way of measuring the perceptions that non-technical decision-makers in key positions may have of the value and benefits of risk analysis.

Another significant aspect is that of cost, which was not addressed by any of the sources of information in this study. The assumption is often made that risk assessments conducted by private service providers are extremely expensive and justified only in relation to considerable trade volumes. On the other hand, Veterinary Administrations in developing countries, with marginal trade volumes, may also claim that it is unjustified to establish and maintain in-house expertise to conduct risk assessments. Building risk assessment capacity, especially for imports, and developing the qualified human resources that it requires, should be considered an important part of the 'fixed costs' of Veterinary Services (17). In fact, from a cost-benefit perspective, these costs are just as worthwhile and justifiable as the investments made in prophylaxis, border inspection or any other preventative measures, aimed at avoiding the introduction of unpredictable, acute and costly disease events. Such core 'public good' investments are intrinsically the responsibility of governments (18).

In future, it may be worthwhile considering more focused research into the costs mentioned above, and the resulting capacity in countries to conduct risk assessments, taking into consideration some of the PVS indicators, such as the existence of a stand-alone risk analysis unit, the technical profiles of the staff involved and the types of databases used to manage relevant information.
In addition, should the OIE, whose mandate is primarily (but not exclusively) to facilitate the international trade of animals and animal products, extend its standards and guidelines to other types of risk assessment, over and above import risk assessments?

A final consideration: this study focuses on the situation in Africa and the assumption could be made that we are dealing with the worst-case scenario of a continent which struggles to participate in the very competitive sector of regional and international movement of animals and animal products. There is, however, no evidence to support (or deny) the premise that the situation in other developing regions of the world may be any better.

\section{Acknowledgements}

The authors wish to express their sincere appreciation and gratitude to Ms Rina Serfontein, Senior Administration Officer and Postgraduate Coordinator at the Department of Veterinary Tropical Diseases of the Faculty of Veterinary Sciences of the University of Pretoria (South Africa); as well as to Dr Bernard Vallat, former OIE Director General, who authorised Dr Patrick Bastiaensen to conduct this study under the auspices of the OIE as part of his dissertation, submitted in October 2016 in fulfilment of the requirements for an MSc degree (Animal-Human-Ecosystems Health) at the University of Pretoria. The authors would also like to acknowledge the assistance of Dr Valentyna Sharandak, of the OIE Regional Activities Department in Paris, for her help in identifying the relevant PVS reports and Dr Julia Punderson, OIE PVS expert and former USDA/APHIS risk assessor.

The full version of the MSc thesis mentioned above can be downloaded at: www.rr-africa.oie.int/docspdf/en/2017/ Bastiaensen_thesis.pdf. 


\title{
Évaluation de la portée et de l'utilisation des méthodes d'analyse du risque en Afrique, d'après les données du Processus PVS d'évaluation des performances des Services vétérinaires
}

\author{
P. Bastiaensen, D. Abernethy \& E. Etter
}

\section{Résumé}

Les pays africains souhaitant accéder aux marchés d'exportation sont confrontés à la réalisation de plus en plus fréquente d'appréciations du risque à l'importation par les pays importateurs, qui cherchent à vérifier les sources d'approvisionnement des marchandises qu'ils importent. D'autres méthodologies d'analyse du risque sont également pratiquées, axées sur la santé animale et la santé humaine au niveau des pays et des communautés.

À partir d'une analyse des évaluations réalisées par l'Organisation mondiale de la santé animale (OIE) au moyen de l'Outil d'évaluation des performances des Services vétérinaires, les auteurs tentent de définir les pratiques actuelles en Afrique ainsi que le niveau de conformité des pays à l'Accord sur l'application des mesures sanitaires et phytosanitaires de l'Organisation mondiale du commerce (" Accord SPS ") et aux normes de l'OIE. Pour ce faire, les auteurs s'appuient également sur l'analyse d'une sélection de rapports d'appréciation du risque.

Les résultats laissent apparaître l'inadéquation des capacités et des compétences techniques dédiées à l'appréciation du risque par rapport aux normes de I'OIE (à l'exception du cas de trois pays), depuis l'absence totale d'appréciation du risque à partir d'éléments documentés et de décisions relevant de la gestion de ce risque (niveau d'avancement 1), jusqu'à des insuffisances concernant un ou plusieurs aspects du processus d'appréciation du risque. Cette analyse est confirmée par une série d'études de cas, dont la moitié a été produite par des consultants internationaux.

Les auteurs recommandent principalement de renforcer les ressources humaines dédiées aux appréciation du risque et de mettre en place des unités dédiées, en déterminant clairement leur mandat, leur fonction, ainsi que les politiques à mener, les procédures applicables et les protocoles à suivre.

\section{Mots-clés}

Accord sur l'application des mesures sanitaires et phytosanitaires - Afrique - Analyse du risque - Animal - Échanges internationaux - Évaluation des performances - Appréciation du risque - Évaluation PVS - Importation - OIE - Organisation mondiale de la santé animale - Organisation mondiale du commerce - Produits d'origine animale - Services vétérinaires.

\section{Evaluación de la implantación y el uso de métodos de análisis de riesgos en África con datos resultantes del Proceso PVS (prestaciones de los Servicios Veterinarios)}

\author{
P. Bastiaensen, D. Abernethy \& E. Etter
}

\section{Resumen}

Cada vez más, los países africanos que desean exportar son sometidos a determinaciones del riesgo de importación por parte de los países importadores, preocupados por la procedencia de las mercancías que importan. A veces 
también se emplean otros métodos y planteamientos de análisis del riesgo, centrados en determinados aspectos zoosanitarios y sanitarios de los países 0 comunidades de origen.

Basándose en un análisis de las evaluaciones realizadas por la Organización Mundial de Sanidad Animal (OIE) con la Herramienta PVS, los autores tratan de aprehender los usos actualmente vigentes en África, así como los niveles de cumplimiento del Acuerdo sobre la Aplicación de Medidas Sanitarias y Fitosanitarias (Acuerdo MSF) de la Organización Mundial del Comercio (OMC) y las normas de la OIE, ayudándose también para ello del estudio de una serie de informes de determinación de riesgos.

Los resultados ponen de relieve la falta de competencias y capacidades técnicas para llevar a cabo determinaciones de riesgos con arreglo a las normas de la OIE (salvo en el caso de tres países), con situaciones que van desde la ausencia absoluta de toda forma de determinación (documentada) de los riesgos y, a partir de ahí, de toda decisión para gestionarlos (nivel de progreso 1), hasta la existencia de uno o varios aspectos defectuosos en el proceso de determinación de riesgos, observación que confirman una serie de estudios monográficos, la mitad de ellos obra de consultores internacionales.

Las principales recomendaciones de los autores apuntan a fortalecer la dotación de recursos humanos para efectuar determinaciones de riesgos y a establecer unidades dedicadas específicamente a esta labor, habiendo definido con toda claridad su mandato, los perfiles que deben integrarlas y sus políticas, procedimientos y protocolos de trabajo.

\section{Palabras clave}

Acuerdo sobre la Aplicación de Medidas Sanitarias y Fitosanitarias - África - Análisis de riesgos - Animal - Comercio - Determinación de riesgos - Evaluación de las prestaciones - Evaluación PVS - Importación - OIE - Organización Mundial de Sanidad Animal Organización Mundial del Comercio - Producto de origen animal - Servicios Veterinarios.

\section{References}

1. World Trade Organization (WTO) (2016). - The WTO Agreement on the Application of Sanitary and Phytosanitary Measures (SPS Agreement). WTO, Geneva. Available at: www. wto.org/english/tratop_e/sps_e/spsagr_e.htm (accessed on 12 March 2016).

2. World Organisation for Animal Health (OIE) (2016). Terrestrial Animal Health Code. OIE, Paris. Available at: www. oie.int/international-standard-setting/terrestrial-code/accessonline/ (accessed on 3 April 2017).

3. World Organisation for Animal Health (OIE) (2010). Handbook on import risk analysis for animals and animal products - Vol. I. Introduction and qualitative risk analysis. OIE, Paris, 88 pp.

4. World Organisation for Animal Health (OIE) (2004). Handbook on import risk analysis for animals and animal products - Vol. II. Quantitative risk assessment. OIE, Paris, $126 \mathrm{pp}$.
5. International Union for the Conservation of Nature (IUCN) \& World Organisation for Animal Health (OIE) (2014). - Guidelines for wildlife disease risk analysis $\&$ Manual of procedures for wildlife disease risk analysis. IUCN, Gland, Switzerland \& OIE, Paris. Available at: www. cbsg.org/content/iucn-manual-procedures-wildlife-diseaserisk-analysis (accessed on 3 April 2017).

6. Codex Alimentarius Commission (CAC) (2007). - Working principles for risk analysis for food safety for application by governments (CAC/GL 62). CAC, Geneva. Available at: www.fao.org/fao-who-codexalimentarius/standards/list-ofstandards/en/ (accessed on 11 March 2016).

7. World Organisation for Animal Health (OIE) (2016). - The OIE PVS pathway. OIE, Paris. Available at: www.oie.int/en/ support-to-oie-members/pvs-pathway/ (accessed on 7 March 2016). 
8. World Organisation for Animal Health (OIE) (2013). - OIE Tool for the Evaluation of the Performance of Veterinary Services (OIE PVS Tool), 6th Ed. OIE, Paris, 56 pp. Available at: www.oie.int/fileadmin/Home/eng/Support_to_OIE_ Members/pdf/PVS_A_Tool_Final_Edition_2013.pdf (accessed on 7 March 2016)

9. World Organisation for Animal Health (OIE) (2015). - Strengthening of Veterinary Services. Bull. OIE, 2015-4, p.55.

10. Simpson B. (2013). - Managing and controlling the threats of avian influenza viruses (AIV) to the ostrich industry of South Africa. Report prepared for the South African Ostrich Business Chamber, Palmerston North, New Zealand, 43 pp.

11. Moshy W. \& Msafiri P.A. (2015). - Risk assessment and proposed management of cattle to be imported from Eldoret, Kenya, to Kagera, Tanzania. Internal risk assessment report. Ministry of Livestock and Fisheries Development of Tanzania, Temeke, Tanzania, 4 pp.

12. Chazya R., Muma J.B., Mwacalimba K.K., Karimuribo E., Mkandawire E. \& Simuunza M. (2014). - A qualitative assessment of the risk of introducing peste des petits ruminants into northern Zambia from Tanzania. Vet. Med. Int., 2014, 202618. doi:10.1155/2014/202618.

13. Sergeant E. (2014). - Import risk analysis: sable antelope from Zambia into South Africa. Report prepared by AusVet Animal Health Services for the Directorate of Animal Health, Department of Agriculture, Forestry and Fisheries (DAFF), Pretoria, 77 pp (draft). Available at: www.nda.agric.za/docs/ media/sable\%20IRA\%20final\%20draft_2014-12-15.pdf (accessed on 7 March 2016).
14. Rich K. (2009). - What can Africa contribute to global meat demand? Opportunities and constraints. Outlook Agric., 38 (3), 223-233. doi:10.5367/000000009789396793.

15. World Trade Organization (WTO) (2016). - SPS information management system. WTO, Geneva. Available at: http:// spsims.wto.org/web/pages/search/stc/Search.aspx (accessed on 15 May 2016).

16. World Organisation for Animal Health (OIE) (2010). - OIE Tool for the Evaluation of the Performance of Veterinary Services (OIE PVS Tool), 5th Ed. OIE, Paris, 56 pp.

17. Rushton J. (2013). - An overview analysis of costs and benefits of government control policy options. In Building bridges between science and economics. Organisation for Economic Co-operation and Development, Paris, 39-51. Available at: www.oecd.org/tad/agricultural-policies/AN\%20 OVERVIEW\%20OF\%20ANALYSIS\%20OF\%20COSTS\%20 AND\%20BENEFITS.pdf (accessed on 24 January 2017).

18. Rushton J. \& Jones D. (2017). - Sustainability and economic investments in animal health systems. In Biological threat reduction (T. Beckham, ed.). Rev. Sci. Tech. Off. Int. Epiz., 36 (2) (in preparation). 